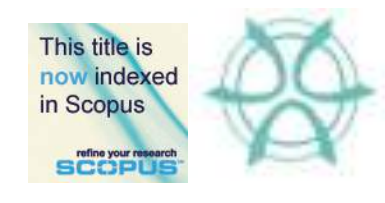

PLANNING MALAYSIA:

Journal of the Malaysian Institute of Planners

SPECIAL ISSUE IV (2016), Page 147 - 162

\title{
AN OVERVIEW OF CRITICAL SUCCESS FACTORS OF PUBLIC- PRIVATE PARTNERSHIP IN THE DELIVERY OF URBAN INFRASTRUCTURE AND SERVICES
}

\author{
Zayyanu Muhammad ${ }^{1}$, Kim Kwang Sik $^{2}$, Foziah Johar $^{3} \&$ Soheil Sabri ${ }^{4}$ \\ ${ }^{1,2,3}$ UNIVERSITI TEKNOLOGI MALAYSIA \\ ${ }^{4}$ UNIVERSITY OF MELBOURNE, AUSTRALIA.
}

\begin{abstract}
The inability of the public sector to independently meet the increasing demand for infrastructure and services has prompted many governments to adopt Public-private partnership (PPP) as an alternative strategy. In worldwide practices, however, there are mixed results and controversy in the application of PPP model. The Public-private partnership has, for this reason, become an increasingly active research area mainly to establish the Critical Success Factors (CSFs) towards improving the PPP model. This article reviews the current debate on the subject of PPP and compares the findings of different literature regarding the relative importance of CSFs of PPP projects. The authors argue that the CSFs of PPP projects are distinctive to the context of location and time. The article concludes that this subjectivity has implications for the "guaranteed" success of both existing and future PPP projects.
\end{abstract}

Keyword: Public-Private Partnership, Critical Success Factors, Infrastructure and Services delivery

\section{INTRODUCTION}

Rapid urban growth throughout the developing world is seriously outstripping the capacity of most cities to provide adequate infrastructure and services for their citizens. Most urban management agencies in developing countries of the world lack the institutional capacity and financial means to carry out many of the development task assigned to them (Agbola 1998). As observed by the UNCHS (1996), the provision of urban infrastructure is overwhelming as the cities appear to be growing beyond management capacities and available resources.

Having recognized the vital role that infrastructure and services play in the socioeconomic development of societies, most governments entrusted their delivery to stateowned enterprises. However, in many places, particularly the developing countries of the world, the results were disappointing because public sector are inefficient (Harris 2003). This inability of the public sector to independently meet the increasing demand for enhanced service delivery (Birner \& Wittmer 2006) has prompted many governments to seek for alternatives strategies (Rakić \& Rađenović 2011). Subsequently, Public-Private Partnership is adopted (Hammami, Ruhashyankiko, \& Yehoue, 2006; Abdel Aziz 2007) 
Zayyanu Muhammad, Kim Kwang Sik, Foziah Johar \& Soheil Sabri

An Overview of Critical Success Factors of Public-Private Partnership in the Delivery of Urban Infrastructure and Services

to help governments cope with the growing demand for public infrastructure and services (Alhomadi 2012).

Over the last three decades, Public-Private Partnership (PPP) has become fashionable (Klijn \& Teisman 2003) around the world due to their benefits in delivering public infrastructure projects. However, in worldwide practices, the experience with PPP has not been totally effective (Batley 1996; Hodge \& Greve 2007b; Jooste \& Scott 2011; Loxley 2013). On one hand, the partnership has been used to deliver a significant number of projects. On the contrary, many partnerships encountered problems and suffered disastrous consequences (Cheung 2009; Alhomadi 2012). Consequently, some PPP projects were either abandoned by the sponsors or bailed by the host governments (Zhang \& Chen 2013). The mixed results and the substantial interest over PPPs, therefore, call for an investigation into the explanatory factors for the success and failure of PPP projects towards the improvement of the model.

This article aims to present an overview of the Critical Success Factors for PublicPrivate Partnership projects. The article discusses the concept, benefits, critical success factors and application of PPP in infrastructure and services delivery through an extensive review of the literature. The article argues that the level of importance of CSFs for PPP projects is idiosyncratic to the dynamics of "location" and "time." The article concludes by highlighting the implications of this subjectivity to the "guaranteed" success of both existing and future PPP projects.

\section{METHODS}

Although the subject of PPP has received wide academic discourse (Van Huijstee et al. 2007), the literature remains largely fragmented (Kivleniece \& Quelin 2012). Also, many researchers presented a narrow review of PPP. They include Pantouvakis \& Vandoros (2006) in construction, Amobi (2013) in infrastructure development and Roehrich et al. (2014) in the health sector. In contrast, the paper provides a broader range of theoretical backgrounds covering a wide spectrum of PPP application.

This article extensively reviewed the normative literature to provide a comprehensive understanding of Public-private partnership in infrastructure and service provision. The paper consolidates the current debate on the meaning, benefits, application and critical success factors of PPP. Having identified their importance within the framework of PPP research, the article focused on Critical Success Factors of PPP projects. The findings of other researchers regarding the relative importance of critical success factors for PPP projects were compared and contrasted. The article then distilled different viewpoints concerning the relative importance of CSFs, and implications for the success of PPP projects are highlighted (Figure 1). 


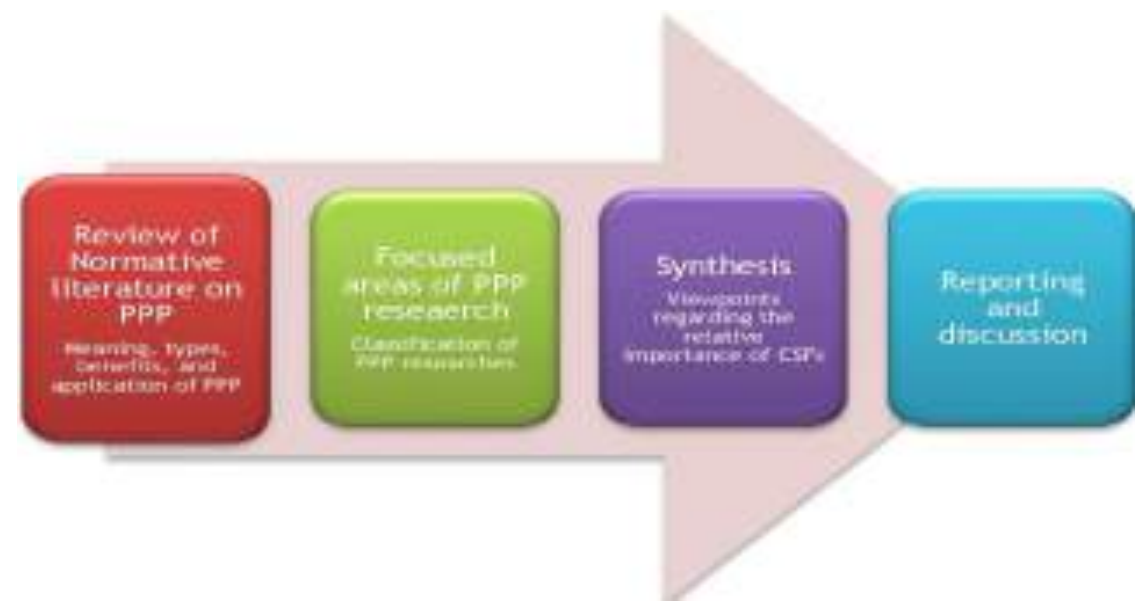

Figure 1: Literature Review Process

\section{THE CONCEPT OF PPP}

Since its conception, about three decades ago, the concept of PPP has been strongly contested (Bovaird 2004). Indeed, the overwhelming number and types of PPP makes a single definition difficult (Idris, Kura, \& Bashir, 2013; Thomson, Goodwin, \& Yescombe 2005). Different scholars, governments, and international organizations have described PPP in diverse perspectives. By seeking to introduce a market mechanism into government business, PPP is described as a derivative of the privatization movement (Savas 2000; Bovaird 2004). As observed by Abdul-Aziz \& Kassim (2011), any attempt to shift government role to a private enterprise is tantamount to privatization.

On the contrary, Jamali (2004) and Lovells Lee and Lee (2009) see PPP as entirely different concept from outright privatization. As argued by Jamali (2004), PPP goes beyond privatization of public services but implies a sort of collaboration between two or more partners to pursue common goals. She argued that such collaboration must involve the joint definition of objectives and clear assignment of responsibilities in pursuit of common goals. The collaborating actors mutually agree to share risks, costs and benefits in the development of products or services (Hammami et al. 2006; Kee \& Forrer 2008). In that regard, HM Treasury (1999) describes PPP as a long-term cooperation between public and private sectors for mutual benefits. The Ministry of Municipal Affairs British Columbia also defines PPP in line with its UK counterpart as "arrangements between government and private sector entities for the purpose of providing public infrastructure, community facilities, and related services. Such arrangement involves sharing of investment, risks, responsibilities and reward between the partners" (P.5: 1999). As submitted by Van Ham \& Koppenjan (2010) PPP involves cooperation between public and private actors in which they jointly develop products and services and share risks, costs, and resources.

Others see PPP as a means of project financing that allows the public sector to reduce its financial constraints by utilizing private sector resources in service provision. As pointed out by Alinaitwe \& Ayesiga (2013), many governments see PPP as a means of launching investment programs that would otherwise not be possible within the 
Zayyanu Muhammad, Kim Kwang Sik, Foziah Johar \& Soheil Sabri

An Overview of Critical Success Factors of Public-Private Partnership in the Delivery of Urban Infrastructure and Services

available public-sector budget. PPP was predominantly viewed as a means of removing infrastructure costs from the public balance sheet and avoid the constraints of publicsector borrowing limits ( $\mathrm{Li}$ et al. 2005). However, the WorldBank (2009) had a contrary view and argued that PPPs should not be merely a means of leveraging private sector resources but as a tool for reforming procurement and public service delivery.

Despite several definitions and perspectives of PPP, the critical elements, that characterized a PPP, as identified by Kwak et al. (2009) are four. First, it involves cooperation (Klijn \& Teisman 2003) between 2 or more partners. According to European Commission (2003), Public-Private Partnership is an agreement between two parties to work together towards a common goal. Although, the partnership is usually between the public and private sectors, the relationship may, however, involve a consortium of third party interests. The third party interest may include lenders, equity investors, and other interests or non-profit groups (Kwak et al. 2009; UN-HABITAT 2011). Second, the partners work cooperatively towards achieving mutual objectives and benefits. In this regards, Jamali (2004) argued that a relationship can be qualified as a partnership if it involves the joint definition of goals and clear assignment of responsibilities in pursuit of common objectives. Third, it is about the introduction of market mechanisms to achieve efficiency in service provision (Grimsey \& Lewis 2004; Babatunde et al. 2012). As explained by Kee \& Forrer (2008), PPP involves the introduction of the managerial skills, entrepreneurship, and expertise of the private sector towards increasing the efficiency of the public sector. The adoption of Private Finance Initiative (PFI) in the UK aims to introduce market discipline into the provision of public services (Hammami et al. 2006; Wall \& Connolly 2009). Fourth, it involves sharing of risk between partners (Grimsey Darrin and Lewis Mervyn K. 2004; Idris et al. 2013). As submitted by Alinaitwe \& Ayesiga (2013), PPPs are risk-sharing investments in the provision of infrastructure and services. The amount of risk transfer differentiates a public-private partnership from traditional procurement. Many relationships may not be considered as partnerships, even where a private company is involved, provided there is no substantial risk transfer.

The underlying logic of establishing a partnership is that both the public and the private sector have unique characteristics that provide them with advantages in particular aspects of service delivery. The principal arguments in favor of public-private partnerships are two. One, it allows for the utilization of private sector resources, expertise, and skills (Ong 2003) to achieve "value for money" (Armitage \& Susilawati 2004). The value for money usually translates to improved quality of service, higher efficiency, and lower costs. Secondly, a partnership is a form of cutting cost strategy that allows the government to reduce the overall cost of social transfers. PPP, therefore, serves as a means to preserve scarce capital resources for other purposes (Muhammed 2008).

The essential feature of PPP is that the client (the public sector) usually define the services needed. The private investor then undertakes to design, build, and finance the operation before handing over at the end of the concession period (Kwak et al. 2009). However, in reality, specific project objectives and requirements determine the structuring of partnership arrangements. Therefore, many types of partnerships models are in use today in the pursuit of different project objectives. The types differ depending on the circumstances and dimensions of the business arrangement and the extent of the responsibilities of partners (Mcquaid 2009). Kwak et al. (2009) described different partnership options along a continuum in line with the extent of responsibilities given to 
each partner in a PPP arrangement (Fig. 2). At one end, is the public provision where the public sector is fully responsible for all aspects of service provision. While, at the other extreme, is the private provision, where the private sector assumes all those responsibilities. Examples of PPP arrangement include Build-Own-Operate (BOO) and Build-Operate-Transfer (BOT), Design-Build-Operate models. The degree of private sector involvement increases along the continuum; and vice-versa.

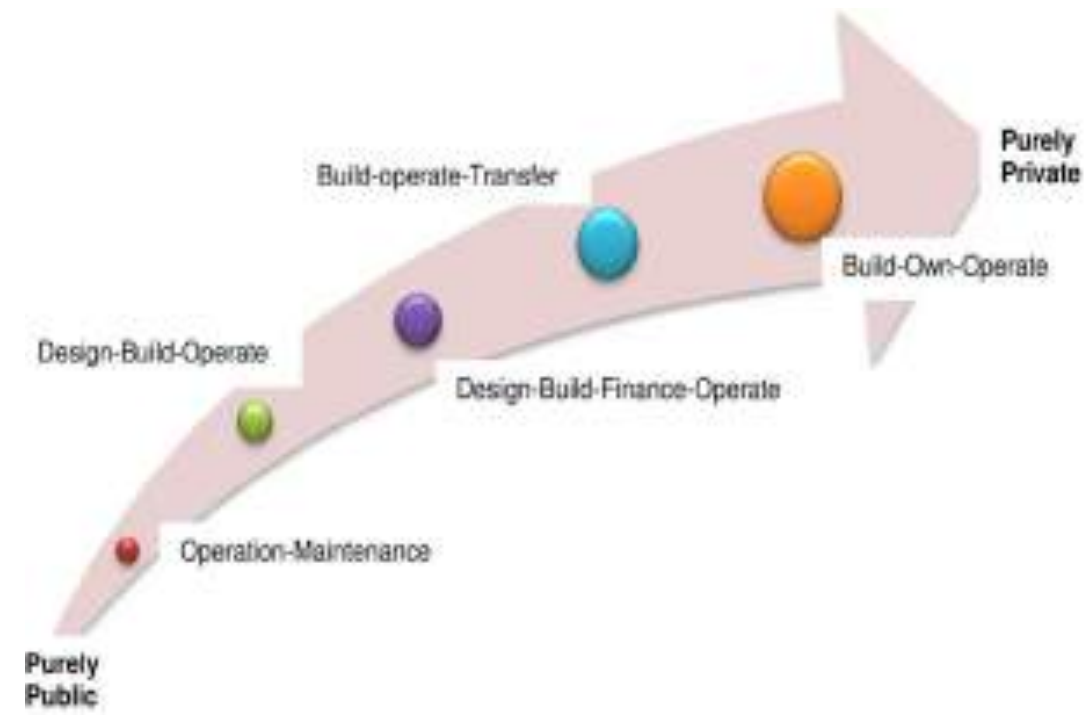

Figure 2: Models of Public-Private Partnership

\section{Classification of PPP Research}

The worldwide interest in PPP and the problems encountered in several countries has called for a better understanding of PPP. Many studies, to answer this call, have investigated five main aspects of PPP as follows:

- The roles and responsibilities of government in PPP (Kumaraswamy \& Zhang 2001; Koch \& Buser 2006; Abdel Aziz 2007)

- $\quad$ The concession selection (Zhang 2004; Zhang \& Kumaraswamy 2001)

- $\quad$ Risks in PPP (Thomas et al. 2003; Bing et al. 2005; Nisar 2007)

- $\quad$ PPP finance (Levy 1996; Zhang 2005)

- Critical success factors for PPP (Qiao et al. 2001; Jefferies et al. 2002; Li et al. 2005; Hardcastle et al. 2005; Jamali 2004b; Wang et al. 2007; Babatunde et al. 2012; Hwang et al. 2013; Ismail 2013)

The conceptual framework (Fig 3) for the classification of PPP research highlights the significance of the Critical Success Factors (CSFs) towards improving PPP for effective service delivery. 


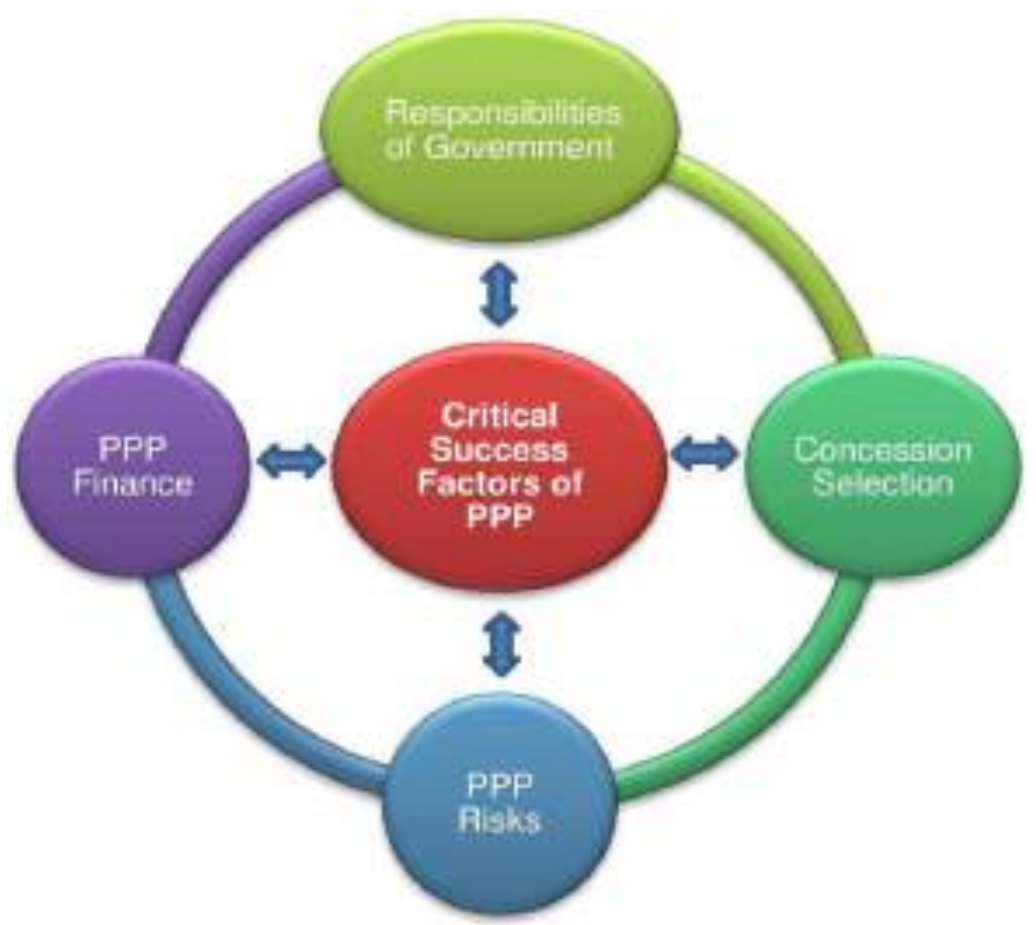

Figure 2: Models of Public-Private Partnership

Research literature suggests that although the appeal for PPP all over the world is growing, systematic examination of the success and failure factors is limited (Jamali 2004b; Alinaitwe \& Ayesiga 2013). The understanding of such factors will allow for the efficient allocation of scarce resources (Zhang 2005; Agrawal 2010) and the establishment of guidelines for PPP activities (Boynton \& Zmud 1984). Such understanding is also required for the development of a workable and efficient PPP framework (Zhang 2005; Kwak et al. 2009). As observed by Milosevic \& Patanakul (2005), critical success factors have a significant impact on the success of a project. Accordingly, many studies, therefore, focused on investigating the CSFs to improve the effectiveness of PPP as a service delivery model.

\section{Critical Success Factors of PPP Projects}

Rockart (1982) defines Critical Success Factors as "those few areas of activity in which favorable results are necessary for a manager to reach his/her goals" (Pg. 4, 1982). CSFs are those key areas that ensure the success of an organization or project (Kwak et al. 2009; Dulaimi et al. 2010; Alias et al. 2014). The CSF approach attempts to isolate key areas that are essential for management to achieve success. The CSF approach originated from management practice. However, it has been applied in financial services (Boynton \& Zmud 1984); information systems (Rockart 1982); Textile industry (Asare 2012) and construction management (Jefferies et al. 2002). 
Many researchers have identified different lists of CSFs of PPP projects based on review of other literature or through empirical studies. For instance, Akintoye et al. (2003) identified success factors that contribute to the achievement of the best value in (PFI) projects in the UK. Qiao et al. (2001) identified eight independent CSFs for Build-OwnTransfer (BOT) in China. Jefferies et al. (2002) identified CSFs from the reflection of an Australian stadium project. Zhang (2005) identified 47 CSFs for PPP projects at the international level. He later classified into five (5) main aspects of CSFs. Kwak et al. (2009) identified CSFs for PPP projects also from an extensive review of the literature (Table 1)

Table 1: List of CSFs in the Reviewed Literature

\begin{tabular}{|c|c|c|c|}
\hline Author(s) & $\begin{array}{l}\text { PPP } \\
\text { Types }\end{array}$ & Regions & Critical Success Factors \\
\hline $\begin{array}{l}\text { Akintoye } \\
\text { et al. } \\
(2003)\end{array}$ & PFI & UK & $\begin{array}{l}\text { Detailed risk analysis and appropriate risk } \\
\text { allocation, drive for faster project completion, } \\
\text { curtailment in project cost escalation, } \\
\text { encouragement of innovation in project } \\
\text { development, and maintenance cost being } \\
\text { adequately accounted for }\end{array}$ \\
\hline $\begin{array}{l}\text { Qiao et al. } \\
\text { (2001) }\end{array}$ & BOT & China & $\begin{array}{l}\text { Appropriate project identification, stable political } \\
\text { and economic situation, attractive financial package, } \\
\text { acceptable toll/tariff levels, and reasonable risk } \\
\text { allocation, selection of suitable subcontractors, } \\
\text { management control, and technology transfer }\end{array}$ \\
\hline $\begin{array}{l}\text { Zhang } \\
\text { (2005) }\end{array}$ & PPP & International & $\begin{array}{l}\text { Economic viability, appropriate risk allocation via } \\
\text { reliable contractual arrangements, sound financial } \\
\text { package, reliable concessionaire consortium with } \\
\text { strong technical strength, and favorable investment } \\
\text { environment }\end{array}$ \\
\hline $\begin{array}{l}\text { Jefferies } \\
\text { et al. } \\
(2002)\end{array}$ & BOOT & Australia & $\begin{array}{l}\text { Solid consortium with a wealth of expertise, } \\
\text { considerable experience, high profile and a good } \\
\text { reputation, an efficient approval process, and } \\
\text { innovation in the financing methods of the } \\
\text { consortium }\end{array}$ \\
\hline $\begin{array}{l}\text { Kwak et } \\
\text { al. (2009) }\end{array}$ & $\begin{array}{l}\text { PPP in } \\
\text { general }\end{array}$ & International & $\begin{array}{l}\text { Competence of the government; selection of an } \\
\text { appropriate concessionaire; appropriate risk } \\
\text { allocation between the public and private sectors; } \\
\text { and a sound financial package }\end{array}$ \\
\hline
\end{tabular}

\section{The Relative Importance of CSFs for PPP Projects}

Many researchers have developed different lists of CSFs of PPP projects. However, while many factors are critical, it is quite obvious that the level of "criticality" of the identified factors varies in different places ( $\mathrm{Li}$ et al. 2005). Accordingly, many studies have focused on investigating the relative importance of CSFs to enhance the understanding of PPP. For instance, $\mathrm{Li}$ et al. (2005) investigated the relative importance of $18 \mathrm{CSFs}$ in the UK and concluded that the three (3) most important factors. Chan et al. (2010) investigated 18 CSFs of PPP in infrastructure development in China. The results of their study identified five underlying factors. Ismail (2013) examined the importance of 18 success factors for PPP implementation in Malaysia and established five top (5) CSFs. Hwang et 
Zayyanu Muhammad, Kim Kwang Sik, Foziah Johar \& Soheil Sabri

An Overview of Critical Success Factors of Public-Private Partnership in the Delivery of Urban Infrastructure and Services

al. (2013) examined the relative importance of positive and negative factors influencing PPP projects in Singapore and discovered eight top factors. Babatunde et al. (2012) also considered the relevance of success factors between the public and private sectors in infrastructure delivery in Nigeria. The results of the study revealed eight critical success factors. Cheung, Albert P.C. Chan et al. (2012) compared the relative importance of 18 CSF for PPP projects in Hong Kong, Australia and the UK. The study indicated that while five CSFs are most critical in Hong Kong, the level of importance of those factors is quite different in Australia and UK (Table 2).

Table 2: Relative Importance of CSFs of PPP Projects

\begin{tabular}{|c|c|c|c|}
\hline Author(s) & PPP TYPES & Regions & Top ranked CSFs \\
\hline $\begin{array}{l}\text { Li et al. } \\
(2005)\end{array}$ & PFI & UK & $\begin{array}{l}\text { A strong and good private consortium, appropriate } \\
\text { risk allocation, and available financial market }\end{array}$ \\
\hline $\begin{array}{l}\text { Cheung et } \\
\text { al. } \\
(2012)\end{array}$ & PPP Projects & $\begin{array}{l}\text { Hong } \\
\text { Kong, } \\
\text { Australia, } \\
\text { UK }\end{array}$ & $\begin{array}{l}\text { Favorable legal framework, commitment and } \\
\text { responsibility of public and private sectors, strong } \\
\text { and strong private consortium, stable } \\
\text { macroeconomic condition and appropriate risk } \\
\text { allocation and risk sharing are the five top success } \\
\text { factors for Hong Kong }\end{array}$ \\
\hline $\begin{array}{l}\text { Ismail, S. } \\
\text { (2013) }\end{array}$ & PPP Projects & Malaysia & $\begin{array}{l}\text { good governance, a commitment by public and } \\
\text { private sectors, favorable legal framework, sound } \\
\text { economic policy, and available financial market are } \\
\text { the top five (5) CSFs in Malaysia }\end{array}$ \\
\hline $\begin{array}{l}\text { Chan et al. } \\
(2010)\end{array}$ & $\begin{array}{l}\text { Infrastructure } \\
\text { Development }\end{array}$ & China & $\begin{array}{l}\text { Stable macroeconomic environment, transparent } \\
\text { and efficient procurement process, shared } \\
\text { responsibility between public and private sectors, } \\
\text { stable political and social environment, and } \\
\text { judicious government control }\end{array}$ \\
\hline $\begin{array}{l}\text { Hwang et } \\
\text { al. } \\
(2013)\end{array}$ & PPP Projects & Singapore & $\begin{array}{l}\text { Well organized public agency, Appropriate risk } \\
\text { allocation and sharing, Strong private consortium, } \\
\text { Transparent procurement process, Clearly defined } \\
\text { responsibilities, Clarification of contract } \\
\text { documents, Favourable legal framework, Shared } \\
\text { authority between public and private sector }\end{array}$ \\
\hline $\begin{array}{l}\text { Babatunde } \\
\text {, et al. } \\
\text { (2012) }\end{array}$ & $\begin{array}{l}\text { Infrastructure } \\
\text { Projects }\end{array}$ & Nigeria & $\begin{array}{l}\text { Competitive procurement process, Thorough } \\
\text { assessment of the cost and benefits, Favorable legal } \\
\text { framework, appropriate risk allocation, } \\
\text { Government guarantee, political support, stable } \\
\text { macroeconomic condition, sound economic policy, } \\
\text { availability of suitable financial market }\end{array}$ \\
\hline
\end{tabular}

From the review of the literature, some authors hold the view that certain critical success factors of PPP projects are common irrespective of geographic location. For instance, the success factor "Favorable legal framework" was found to be critical in both mainland China and Hong Kong (Cheung, Albert P C Chan et al. 2012). On the other hand, other authors (Zhang 2005; Brown et al. 2006; Mu et al. 2011) are of the opinion that critical success factors of PPP projects vary in different administrative settings. The authors argued that because CSFs are place-specific, their level of importance tends to 
vary in different administrative contexts. Akintoye et al. (2003) also concluded that the achievement of optimum efficiency (success) in PPP projects is project-specific as the requirements for achieving it for one project may not be the solution for another. Although, the concept, process and key principles of PPP are essentially identical; many aspects of PPP are either project, sector and country-specific (Zhang \& Chen 2013). As submitted by Zhang (2005), environmental peculiarities influence the success of PPP projects. For this reason, the relative importance of CSFs of PPP projects is determined by the specifics of political, cultural and institutional context (Mu et al. 2011; Brown et al. 2006).

\section{REPORTING AND DISCUSSION}

Many studies investigated and developed a different list of factors that are critical to the success of PPP projects. However, there seems to be an agreement on the relevance of some of the factors due to the recognition they received in the various literature (Table 3 ). The analysis records the number of times the reviewed literature mentioned each factor.

Table 3: Relevancy of CSFs of PPP Projects

\begin{tabular}{|c|c|c|c|c|c|c|c|c|c|c|c|c|c|c|c|}
\hline \multirow{2}{*}{$\begin{array}{l}\mathbf{S} / \mathbf{N} \\
\mathbf{0}\end{array}$} & \multirow{2}{*}{$\begin{array}{l}\text { Critical Success } \\
\text { Factors }\end{array}$} & \multicolumn{13}{|c|}{ Authors } & \multirow{2}{*}{$\begin{array}{l}\text { Frequ } \\
\text { ency }\end{array}$} \\
\hline & & 1 & 2 & 3 & 4 & 5 & 6 & 7 & 8 & 9 & $\begin{array}{l}1 \\
0\end{array}$ & $\begin{array}{l}1 \\
1\end{array}$ & $\begin{array}{l}1 \\
2\end{array}$ & $\begin{array}{l}1 \\
3\end{array}$ & \\
\hline 1 & $\begin{array}{l}\text { Competitive/Trans } \\
\text { parent procurement } \\
\text { process }\end{array}$ & & $*$ & $*$ & & $*$ & $*$ & & & & $*$ & & & & 5 \\
\hline 2 & $\begin{array}{l}\text { Transparent and } \\
\text { efficient legal } \\
\text { framework }\end{array}$ & & $*$ & & $*$ & $*$ & $*$ & $*$ & & & & & & & 5 \\
\hline 3 & $\begin{array}{l}\text { Appropriate risk } \\
\text { allocation and } \\
\text { sharing }\end{array}$ & & & & & $*$ & $*$ & & $*$ & $*$ & & & $*$ & & 4 \\
\hline 4 & $\begin{array}{l}\text { Strong private } \\
\text { concessionaire }\end{array}$ & $*$ & & & $*$ & & $*$ & & $*$ & $*$ & & & & & 4 \\
\hline 5 & $\begin{array}{l}\text { Judicious } \\
\text { government control }\end{array}$ & & & $*$ & & & $*$ & & & & $*$ & & & $*$ & 4 \\
\hline 6 & $\begin{array}{l}\text { Favorable } \\
\text { investment } \\
\text { environment }\end{array}$ & & $*$ & $*$ & & $*$ & & & & $*$ & & & & & 4 \\
\hline
\end{tabular}

Similarly, the review presented two divergent views from the reviewed literature regarding the relative importance of CSFs of PPP projects. On one hand, proponents hold the views that CSFs of PPP projects are, indeed, common irrespective of geographic location. On the contrary; opponents maintained that CSFs are location-specific. For instance, Cheung, Albert P. C. Chan et al. (2012) compared the relative importance of 18 CSFs for PPP projects in Hong Kong, Australia and the UK (Fig 4). They observed that 
the factor "stable macroeconomic condition" is considered top success factor in Hong Kong. However, the same factor was rather unimportant due to a relatively stable economic condition in Australia and the UK. Similarly, while respondents in Hong Kong also ranked "favorable legal framework" top success factor, respondents in Australia and the UK were not very much concerned about their existing legal framework. The ranking is because Australia and the UK have an already established legal system to handle PPP matters.

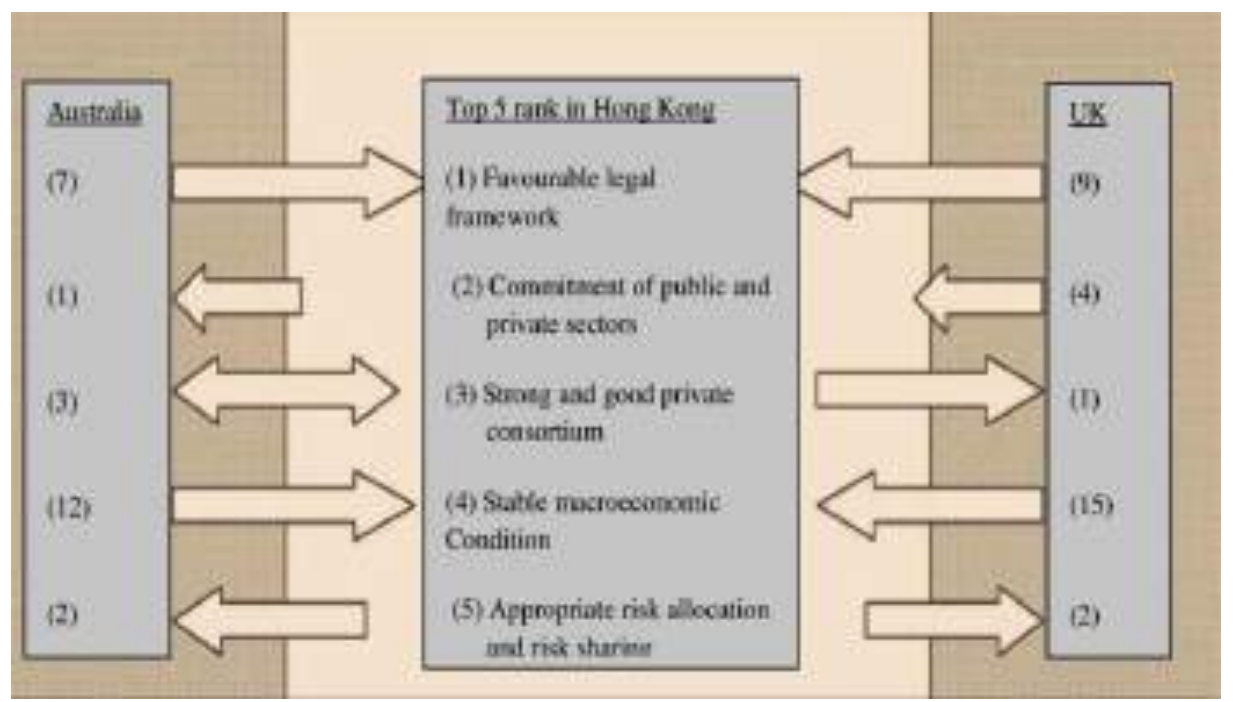

Figure 4: Relative importance of CSFs in Hong Kong, Australia, and the UK Source: Cheung et al. 2012

The two viewpoints have received credence in literature. However, another significant consideration implied from the reviewed literature is that of "time" dimension as an essential element that influences the criticality of CSFs for PPP projects. For instance, $\mathrm{Mu}$ (2008) attributed the failure of a highway project in China to time-related factor. He observed that the absence of adequate laws and regulations for PPP construction and operation in the 1980s caused the failure of "Shen-Da Expressway." Similarly, Chan et al. (2010) identified the success the factor "macroeconomic environment" as very critical in a study in China in 2010. He, however, recognized that the level of criticality of the same factor is likely to change due to the then prevailing changes to the global financial climate. Similarly, Li et al. (2005) attributed the criticality of the success factor "favorable legal framework" to the absence of any specific law on PPP projects in the UK in 2005. However, Cheung, Albert P.C. Chan et al. (2012) discovered that the same factor "favorable legal framework" was not important in the UK seven years later. They ascribed the "change" in the importance of the factor to a wellestablished legal framework in the UK in 2013. For this reason, a factor identified as critical at a time, may due to changing circumstances, be no longer be of importance at a later date. 
The identification of the "time" factor as a determinant of the relative importance of CSFs has far and wide reaching implications. The socio-political and economic systems of many countries and administrative regions are complex and dynamic. This complexity implies that simply focusing on a factor identified as critical for a particular PPP project in a particular context, may not guarantee the success of similar PPP projects in another context. Similarly, focusing on a factor identified as critical at a given time, may not guarantee the success of another PPP project in the same context at a later date. The continuous evolution of PPP procurement process, therefore, requires an ongoing evaluation of PPP projects so as to prioritize the relevant CSFs for efficient delivery of PPP projects.

\section{CONCLUSION}

This article distilled the CSFs for PPP projects and crystallized the various viewpoints concerning the relative importance of Critical Success Factors of Public-Private Partnership projects. The authors also argue that other than a project and location-related factors, the time factor also has a significant influence on the level of importance of the factors considered critical to the success of Public-Private Partnership projects. The paper buttresses the subjectivity regarding the significance of CSFs for Public-Private Partnership projects. Given this subjectivity, future studies on PPP projects may want to reassess the efficacy of the CSFs for PPP projects on a continuous basis. While this study has re-resonated the "timing" as a factor, solutions for improving PPP projects on this factor are limited. Future research agenda may, therefore, explore the influence and dynamics of "time-related" factors on the success of PPP projects. 
Zayyanu Muhammad, Kim Kwang Sik, Foziah Johar \& Soheil Sabri

An Overview of Critical Success Factors of Public-Private Partnership in the Delivery of Urban Infrastructure and Services

\section{REFERENCES}

Abdel Aziz, A.M., 2007. Successful Delivery of Public-Private Partnerships for Infrastructure Development. Journal of Construction Engineering and Management, 133(12), pp.918-931.

Abdul-Aziz, A.R. \& Kassim, P.S.J., 2011. Objectives , success and failure factors of housing public - private partnerships in Malaysia. Habitat International, 35(1), pp.150-157.

Agbola, T., 1998. The Housing of Nigerians : A Review of Policy Development and Implementation. Research Report Number 14, the Development Policy Centre, pp. $2-4$

Agrawal, R., 2010. Successful Delivery of Public-Private Partnerships for Infrastructure Development. Jaypee Institute of Information Technology, Noida, India.

Akintoye, A. et al., 2003. Achieving best value in private finance initiative project procurement. Construction Management and Economics, 21(5), pp.461-470.

Alhomadi Ahmad, 2012. Public-Private Partnership Implementations in Saudi Arabia Infrastructure. University of Calgary, Alberta.

Alias, Z. et al., 2014. Determining Critical Success Factors of Project Management Practice : A conceptual framework. Procedia - Social and Behavioral Sciences, 153, pp.61-69.

Alinaitwe, H. \& Ayesiga, R., 2013. Success Factors for the Implementation of Public Private Partnerships in the Construction Industry in Uganda. Journal of Construction in Developing Countries, 18(2), pp.1-14.

Amobi, I.C., 2013. Public-Private Partnership as a Model for Infrastructural Development in Nigerian Universities. , (April), pp.1-10.

Armitage, L. \& Susilawati, C., 2004. Do Public Private Partnerships Facilitate Affordable Housing Outcomes in Queensland. Australian Property Journal, 2004.

Asare, I.T., 2012. Critical Success Factors for the revival of the Textile Sector in Ghana. International Journal of Business and Social Science, 3(2), pp.307-310.

Babatunde, S.O., Opawole, A. \& Akinsiku, O.E., 2012. Critical success factors in publicprivate partnership ( PPP ) on infrastructure delivery in Nigeria. , 10(3), pp.212225.

Batley, R., 1996. Public private partnerships and performance in Service Provision. Urban Studies, 33(4-5), pp.723-751.

Bing, L. et al., 2005. The allocation of risk in PPP/PFI construction projects in the UK International Journal of Project Management, 23(1), pp.25-35.

Birner, R. \& Wittmer, H., 2006. Better public sector governance through partnership with the private sector and civil society: the case of Guatemala's forest administration. International Review of Administrative Sciences, 72, pp.459-472.

Bovaird, T., 2004. Public-Private Partnerships: from Contested Concepts to Prevalent Practice. International Review of Administrative Sciences, 70(2), pp.199-215.

Boynton, A.C. \& Zmud, R.W., 1984. An Assessment of Critical Success Factors. Sloan Mnagement Review, 25(4), p.11.

Brown, A., Orr, A. \& Lou, J., 2006. The suitability of Public Private Partnerships in the provision of sustainable housing in China. World Review of Entrepreneurship, Management and Sustainable Development, 2(1/2), p.101. 
Chan, A.P.C. et al., 2010. Critical Success Factors for PPPs in Infrastructure Developments: Chinese Perspective. Journal of Construction Engineering and Management, 136(5), pp.484-494.

Cheung, E., Chan, A.P.C., et al., 2012. A comparative study of critical success factors for public private partnerships (PPP) between Mainland China and the Hong Kong Special Administrative Region. Facilities, 30(13/14), pp.647-666.

Cheung, E., 2009. Developing a best practice framework for implementing public private partnerships (PPP) in Hong Kong. Queensland University of Sceince and Technology.

Cheung, E., Chan, A.P.C. \& Kajewski, S., 2012. Factors contributing to successful public private partnership projects: Comparing Hong Kong with Australia and the United Kingdom. Journal of Facilities Management, 10(1), pp.45-58.

Davidson, M.N. \& Malloy, R.P. eds., 2009. Affordable Housing and Public-Private Partnerships, Farnham, England: Ashgate Publishing Company.

Dulaimi, M.F. et al., 2010. The execution of public - private partnership projects in the UAE The execution of public - private partnership projects in the UAE. Construction Management and Economics, 28(4), pp.393-402.

European Commission, 2003. Guidelines for successful public-private partnerships, Available at: http://www.portal-vz.cz/getmedia/ [Accessed November 20, 2014].

Grimsey, D. \& Lewis, M.K., 2004. Public private partnerships: the worldwide revolution in infrastructure provision and project finance, Massachusetts: Edward Elgar Publishing,INC.

Van Ham, H. \& Koppenjan, J., 2010. Building Publi-Private Partnerships: Assessing and managing risks in port development. Public Management Review, 3(4), pp.593616.

Hammami, M., Ruhashyankiko, J. \& Yehoue, E.B., 2006. Determinants of Public-Private Partnerships in Infrastructure, IMF Working Paper, WP/06/99, pp.1-39

Hardcastle, C. et al., 2005. Critical Success Factors for PPP / PFI Projects in the UK Construction Industry: A Factor Analysis Approach. Construction Management and Economics, 23(5), pp.1-9.

Harris, C., 2003. Private Participation in Infrastructure in Developing Countries, Washington DC.

HM Treasury, 1999. Government construction procurement guidelines.

Hodge, G.A. \& Greve, C., 2007a. Public - Private Partnerships: An International Performance Review. Public Administration Review, pp.545-558.

Hodge, G.A. \& Greve, C., 2007b. Public Private Partnerships: An International Performance Review. Public Administration Review, 67, pp.545-558.

Van Huijstee, M.M., Francken, M. \& Leroy, P., 2007. Partnerships for sustainable development: a review of current literature. Environmental Sciences, 4, pp.75-89.

Hwang, B.-G., Zhao, X. \& Gay, M.J.S., 2013. Public private partnership projects in Singapore: Factors, critical risks and preferred risk allocation from the perspective of contractors. International Journal of Project Management, 31(3), pp.424-433.

Idris, A., Kura, S.M. \& Bashir, M.U., 2013. Public Private Partnership in Nigeria and Improvement in Service Delivery : An appraisal. Journal of Humanities and Social Science, 10(3), pp.63-71. 
Zayyanu Muhammad, Kim Kwang Sik, Foziah Johar \& Soheil Sabri

An Overview of Critical Success Factors of Public-Private Partnership in the Delivery of Urban Infrastructure and Services

Ismail, S., 2013. Critical success factors of public private partnership ( PPP ) implementation in Malaysia. Asia-Pacific Journal of Business Administration, 5(1), pp.6-19.

Jamali, D., 2004a. A Public-Private Partnership in the Lebanese Telecommunications Industry: Critical Success Factors and Policy Lessons. Public Works Management \& Policy, 9(2), pp.103-119.

Jamali, D., 2004b. Success and failure mechanisms of public private partnerships ( PPPs ) in developing countries. The International Journal of Public Sector Managemant, 17(5), pp.414-430.

Jefferies, M., Gameson, R.O.D. \& Rowlinson, S., 2002. Critical Success Factors of the BOOT Procurement System : Reflections from the Stadium Australia Case Study. Engineering, Construction and Architectural Management, 9(4), pp.352-361.

Jooste, S.F. \& Scott, W.R., 2011. The Public-Private Partnership Enabling Field: Evidence From Three Cases. Administration \& Society, 44(2), pp.149-182.

Kee, J.E. \& Forrer, J., 2008. Private Finance Initiative — The Theory Behind Practice. International Journal of Public Administration, 31(March 2014), pp.151-167.

Kivleniece, I. \& Quelin, B. V., 2012. Creating and capturing value in public-private ties: A private actor's perspective. Academy of Management Review, 37, pp.272-299.

Klijn, E. \& Teisman, G., 2003. Institutional and strategic barriers to public-private partnership: An analysis of Dutch cases. Public money and Management, (September), pp.9-11.

Koch, C. \& Buser, M., 2006. Emerging metagovernance as an institutional framework for public private partnership networks in Denmark. International Journal of Project Management, 24(7), pp.548-556.

Kumaraswamy, M.M. \& Zhang, X.Q., 2001. Governmental role in BOT-led infrastructure development. International Journal of Project Management, 19(4), pp.195-205.

Kwak, Y.H., Chih, Y. \& Ibbs, C.W., 2009. Towards a Comprehensive Understanding of Public Private Partnerships for Infrastructure Development. California Management Review, 51(2), pp.51-78.

Levy, S.M., 1996. Build, Operate, Transfer: Paving the Way for Tomorrow's Infrastructure, (New York: Wiley and Sons, Inc. Available at: books.google.com.

Li, B. et al., 2005. Critical success factors for PPP/PFI projects in the UK construction industry. Construction Management and Economics, 23(5), pp.459-471. Lovells Lee and Lee, 2009. Privatisation and Public Private Partnerships in Singapore. p.24.

Loxley, J., 2013. Are public - private partnerships ( PPPs ) the answer to Africa's infrastructure needs? Review of African Political Economy, (March 2014), pp.3741.

Mcquaid, R.W., 2009. "Theory of Organisational Partnerships-partnershp advantages, disadvantages and success factors", in: S. P. Osborne (ed) The New Public Governance: Critical Perspectives and Future Directions (Routledge, London), pp. 125-146. , pp.1-29.

Milosevic, D. \& Patanakul, P., 2005. Standardized project management may increase development projects success. International Journal of Project Management, 23, pp.181-192. 
Ministry of Municipal Affairs British Columbia, 1999. Public-Private Partnership A Guide for Local Government, Available at: http://www.lexmundi.com/, [Accessed October 9, 2014].

$\mathrm{Mu}, \mathrm{R} ., 2008$. Public-Private Partnerships and the Management of Expressways in China: An Agency Theory Approach. Delft University of Technology.

$\mathrm{Mu}$, R., Jong, M. de \& Koppenjan, J., 2011. The rise and fall of Public-Private Partnerships in China: a path-dependent approach. Journal of Transport Geography, 19(4), pp.794-806.

Muhammed, Z., 2008. An Appraisal of Kebbi State Community-Based Poverty Reduction Project (CPRP). Ahmadu Bello University, Zaria.

Nisar, T.M., 2007. Risk management in public-private partnership contracts. Public Organization Review, 7(1), pp.1-19.

Ong, H.C., 2003. A New Model of Public-Private Partnerships for Affordable Housing in Malaysia. University of Salford, UK.

Pantouvakis, J. \& Vandoros, N., 2006. A Critical Review of Published Research on PFI / PPPs in Construction. In Construction Symposium on Sustainability and Value through Construction Procurement. Manchester, UK.: CIB, pp. 410-419.

Qiao, L. et al., 2001. Framework for Critical Success Factors of BOT Projects in China. The Journal of Project Finance, 7(1), pp.53-61.

Rakić, B. \& Rađenović, T., 2011. Public-private partnerships as an instrument of new public management. Facta universitatis-series: Economics and Organization, 8, pp.207-220.

Rockart, J.F., 1982. The Changing Role of Information Systems Executive: A Critical Success Factors Perspective,

Roehrich, J.K., Lewis, M.A. \& George, G., 2014. Are public-private partnerships a healthy option? A systematic literature review. Social Science and Medicine, 113, pp.110-119.

Savas, E., 2000. Privatization and the new public management. Fordham Urban Law Journal, 28(5), p.10.

The WorldBank, 2009. Attracting Investors to African Public-Private Attracting Investors to African Public-Private: Aproject Preparation Guide, Washington DC.

Thomas, A. V., Kalidindi, S.N. \& Ananthanarayanan, K., 2003. Risk perception analysis of BOT road project participants in India. Construction Management and Economics, 21(4), pp.393-407.

Thomson, C., Goodwin, J. \& Yescombe, E., 2005. Evaluation of PPP projects financed by the EIB. European Investment Bank. Available at: http://scholar.google.com/scholar [Accessed November 5, 2014].

UNCHS, 1996. An Urbanising World: Global Report on Human Settlements 1996, Oxford. Available at: http://www.alnap.org/resource/.

UN-HABITAT, 2011. Public-private partnerships in housing and urban development, Nairobi: UN-HABITAT.

Wall, A. \& Connolly, C., 2009. The Private Finance Initiative. Public Management Review, 11(5), pp.707-724. Available at: http://www.tandfonline.com/doi/abs/10.1080/14719030902798172 [Accessed November 5, 2014]. 
Zayyanu Muhammad, Kim Kwang Sik, Foziah Johar \& Soheil Sabri

An Overview of Critical Success Factors of Public-Private Partnership in the Delivery of Urban Infrastructure and Services

Wang, W.X. et al., 2007. Critical success factors of infrastructure projects under PPP model in China. In 2007 International Conference on Wireless Communications, Networking and Mobile Computing, WiCOM 2007. pp. 4965-4969.

Zhang, X., 2005. Critical Success Factors for Public-Private Partnerships in Infrastructure Development. Journal of Construction Engineering and Management, 131(1), pp.3-14.

Zhang, X., 2004. Improving Concessionaire Selection Protocols in Public/Private Partnered Infrastructure Projects. Journal of Construction Engineering and Management, 130(5), pp.670-679.

Zhang, X. \& Chen, S., 2013. A systematic framework for infrastructure development through public private partnerships. IATSSR, 36(2), pp.88-97.

Zhang, X.Q. \& Kumaraswamy, M.M., 2001. Hong Kong Experience in Managing BOT Projects. Journal of Construction Engineering and Management, March/Apri, pp.154-162. 